\title{
EDITORIAL
}

Open Access

\section{Gendered dynamics of transnational social protection}

\author{
Başak Bilecen ${ }^{1,2^{*}} \mathbb{D}$, Karolina Barglowski ${ }^{3}$, Thomas Faist ${ }^{2,4}$ and Eleonore Kofman ${ }^{5}$
}

\author{
* Correspondence: b.bilecen@rug.nl; \\ https://www.rug.nl/staff/b.bilecen/; \\ https://ces.fas.harvard. \\ edu/people/basak-bilecen \\ 'Department of Sociology, \\ University of Groningen, Grote \\ Rozenstraat 31, 9712 TG Groningen, \\ the Netherlands \\ ${ }^{2}$ Center on Migration, Citizenship \\ and Development, Bielefeld \\ University, Bielefeld, Germany \\ Full list of author information is \\ available at the end of the article
}

\begin{abstract}
Social protection refers to resources and strategies to deal with social risks, such as poverty or obligations and needs of care, which might impede the realization of life chances and well-being. Previous research has shown that migrants are particularly affected by challenges when accessing or providing social protection, because of unfamiliar welfare regulations in the immigration country and their family and friends being located in various locations, calling for an investigation of gendered dynamics in transnational spaces. In this special issue we aim to advance these vital debates by elucidating the social consequences of the articulation and organization of formal and informal social protection across borders for different actors involved through a joint investigation of gender and transnationality as key dimensions of social inequality. More specifically, the papers collected in this special issue are devoted to investigating the link of formal and informal dimensions of transnational social protection and showing its impact on unequal life chances of mobile people in Europe. This introduction frames the articles collected in this special issue from an inequality perspective, thereby pointing to the ways in which gender and transnationality interact with other dimensions of inequality in the field of social protection, which currently constitutes one of the most vital issues in the field of migration scholarship.
\end{abstract}

Keywords: Transnational social protection, Gender, Inequality, International migration, Welfare state

\section{Springer Open}

\section{Introduction}

Although most people change their place of residence to improve their life chances, international migration often involves a series of social risks such as exclusion from different social or institutional networks, as well as poverty and underemployment. It has been argued that international migration and inequality are inextricably linked (Amelina, 2017; Faist, 2019; Faist \& Bilecen, 2015; Jasso, 2011). This special issue focuses on social protection which refers to resources and strategies to deal with such social risks that might impede the realization of life chances (Faist, Bilecen, Barglowski, \& Sienkiewicz, 2015) especially because they aim to enhance life chances and wellbeing (Locke, Seeley, \& Rao, 2013). Although migrants differ in many respects, they tend to face particular challenges in rearranging their social protection from one welfare regime to another in line with their legal statuses, as well as with their needs, abilities, requirements, and expectations. Those rearrangements can be in the realms of education health care or workplace as well as in their personal and kin relationships

(C) The Author(s). 2019 Open Access This article is distributed under the terms of the Creative Commons Attribution 4.0 International License (http://creativecommons.org/licenses/by/4.0/), which permits unrestricted use, distribution, and reproduction in any medium, provided you give appropriate credit to the original author(s) and the source, provide a link to the Creative Commons license, and indicate if changes were made. 
providing them a safety net in relation to socio-economic resources and care arrangements. We conceptualize social protection as an assemblage composed of formal (opportunity structures codified in nation-state rules and regulations) and informal elements (resources embedded in personal networks) (Bilecen \& Barglowski, 2015). In the context of migration, these entanglements between formal and informal protection are embedded in the wider hierarchies operating along gender, age, ethnicity, and class (Amelina, 2017; Anthias, 2016) within the framework of employment situations and the existence of bilateral agreements between their state of origin and destination. All papers in this special issue analyse the linkage of formal and informal dimensions of transnational social protection and show its impact on unequal life chances of mobile people. Specifically, they draw attention to how social protection provided between family and friends plays out in the specific opportunity structure of formal protection in a transnational perspective.

In both realms of social protection an understanding of gendered practices and norms is crucial. However, an isolated view on gender alone obscures the relationality and internal differentiation of social categories which operate alongside intersectional hierarchies. As such, gender needs to be approached as to its relationality, as "the set of mutually constitutive structures and practices which produce gender differentiation, gender inequalities, and gender hierarchy in a given society" (Orloff, 1996, p. 52). Its internal differentiation plays out in the often ambiguous links with life chances and structures of inequalities because gender norms have "both positive and possibly negative effects in terms of social advancement and disadvantage, for example depending on their social milieu and its structures of opportunities and exclusions" (Anthias, 2009, p. 7). Thus, all the contributions in this special issue are concerned with the central questions: (1) What is expected of men and women in terms of transnational social protection and how do these affect gendered life chances in transnational social spaces? (2) How does this negotiation of social protection influence gender roles and (in-)equalities? (3) Do different areas of social protection, such as healthcare, childcare or financial exchanges have different gendered dynamics?

Previous research has illustrated the differential access to and outcomes with respect to social protection along gender lines in the provision of care within and across borders (Boccagni, 2014; Parreñas, 2008). On the one hand, in the realm of formal social protection, mainly provided by welfare states and their institutions, a plethora of studies indicate the gendered implications, such as the way child benefits, institutional childcare, parental leave and elderly care are arranged but which usually reinforce gendered task division within households and families (Daly \& Lewis, 2000; Haberkern, Schmid, \& Szydlik, 2013; Pfau-Effinger, 2005). On the other hand, in the realm of informal social protection, exchanges within interpersonal networks rely mainly on women's unpaid work or unpaid care in families as part of social reproduction (Kofman, 2014; Kofman \& Raghuram, 2015). Current scholarship has moved away from conceptualizing social protection as a local and national issue, demanding local resources and people, recently transnational implications of social protection have been discussed (Boccagni, 2014, 2017; Faist et al., 2015; Levitt, Viterna, Mueller, \& Llyod, 2017). We engage in those debates by elaborating the ways in which gender as a relational category interacts with other dimensions of inequality, thus offering examples on the various life worlds and 
identities of men and women in the realm of transnational social protection. We also move forward in offering insights into the transformation of gendered dynamics in relation to men, masculinities and patriarchy as distinct features of transnational social protection. Also, the articles collected in this special issue cover other fields of social protection besides care, which takes a central role in the field of social protection, such as access to financial resources.

Transnational social protection is a vital field to observe the complexities in which gender operates together with other markers of difference such as ethnicity, age, transnationality, and class. Transnational spaces link a variety of social spaces across nation-state borders, and thus "enable us to consider social and symbolic attachments to more than one nation-state", as well as acknowledging that "nowadays many individuals and their personal networks are not situated within one single (welfare) state over their life course" (Bilecen \& Barglowski, 2015, p. 204; also, Faist, 2014; Levitt et al., 2017). In this special issue we follow the most recent inequality research, which argues that inequalities nowadays relate to stratification alongside social divisions of gender, ethnicity and class (and more), which intersect at local, national and transnational level (Amelina, 2017; Anthias, 2016). The position in those socio-spatial hierarchies determines access to material and symbolic resources, social status and power. At the same time, the intersections in transnational spaces can produce contradictory social positions, as is the case when migrants have a high social status in their emigration country but hold a lower, racialized position in the immigration country. The uneven patterns of insertion into socio-spatial hierarchies call for an inclusion of spatiality into analysis of inequality. Hence, we include here transnationality as a social category which intersects with gender, class and ethnicity. The transnational perspective taken here denotes the activities and location of people and groups across borders; "transnationality encompasses a whole spectrum of crossborder transactions in various spheres of social life - familial, sociocultural, economic and political - ranging from travel to remittances and the multiple ties involved in these practices, to the exchange of thoughts and ideas" (Faist, 2014, p. 212). A transnational perspective, thus, allows for the acknowledgement that migrants are subject to a variety of meanings and cultural norms. In the area of social protection, this includes negotiating one's own needs in light of opportunity structures, like availability and accessibility of formal social protection. Previous research has shown that accessibility cannot be derived from the mere existence of formal structures, but that migrants organize social protection in line with their own and their families' life course considerations and norms of social protection (Bilecen \& Barglowski, 2015; also, Seibel \& Hedegaard, 2017). Therefore, contributions in this special issue are grounded in various empirical cases and forms of social protection and they all draw attention to the complexity of processes through which gender intersects with other social categories, such as ethnicity and class, in the realm of formal and informal social protection. They address migrants' resources and strategies which largely depend on their position in transnational hierarchies (see also Weiss, 2005). In doing so, the papers aim to avoid methodological nationalism (Glick Schiller \& Wimmer, 2003) and static, localized views on gender, ethnicity, and class. 


\section{Transnational social protection and its gendered implications}

Previous studies on social protection and migration focused on migrants' access to welfare state provisions in immigration countries and indicated the ways in which migration challenges the welfare states (Brücker et al., 2002; Dörr \& Faist, 1997; Sainsbury, 2006). Another branch of literature addresses the gendered dynamics of transnational migration, family ties and care, predominantly focusing on parents (and usually mothers) who migrate without their children (Parreñas, 2001; 2005) and/or who migrate to take care of other people's children (Lutz, 2017) and the elderly (Cangiano, Shutes, Spencer, \& Leeson, 2009). The informal and formal conjunction of social protection has also been acknowledged (Sabates-Wheeler \& Feldman, 2011; Serra Mingot \& Mazzucato, 2018). Yet the nexus of formal and informal social protection and in particular the inequality implications in migration studies require further analysis. It is precisely here that this special issue aims to contribute, by drawing attention to the challenges of the transnational arrangements of social protection between friends and family as well as to the complexities of navigating between different systems of formal protection.

Migration and transnational formations often challenge social protection arrangements for those who migrated, as social policies are usually bound to nation-states, and access is often restricted by legal status or labour market performance. But also, significant others who play an important role in migrants' lives, both in the emigration and immigration countries, are influenced by migration and transnational arrangements of social protection. Vullnetari and King (2008) have explored the experiences of older people in Albania to cope with the situation when many of their younger generations emigrate from the country and the impacts of such a situation on intergenerational care regimes. The EU as the receiving context complicates the formal dimension further as migrants' legal rights within the EU are a mixture of supranational and national regulations of the member states depending on the migration type. In the EU in particular, with easy opportunities for travel and accommodation, "mobile" or "flying" grandmothers have become a prominent form of transnational family care (Kilkey, Plomien, \& Perrons, 2014). The papers in the special issue are thus grounded on the approach of social protection comprised of formal and informal elements and the ways in which they are assembled in the EU as the receiving context.

The papers in this special issue follow up on the ongoing discussions on migrants' social protection by adding a gender and intersectional lens on formal and informal social protection linkages and their implications for life chances in transnational social spaces that previous studies analysed separately. Moreover, prior research has shown how migrants' social protection is linked with inequalities in life chances. Research has extensively analysed inequalities in migrants' access to formal protection (MacAuslan \& Sabates-Wheeler, 2011; Van Ginneken, 2013). With regards to informal protection it has also shown the manifold inequalities of migrants, in particular focusing on the hardships women face in the realm of care (Boccagni, 2014, 2017) and the differential access to social protection due to inequality within (transnational) families (Caarls, Haagsman, Kraus, \& Mazzucato, 2018). For instance, migrants often find it hard to ask for support, in particular financial help, as they are supposed to fare better in a more affluent country (Barglowski, 2019a). At the same time, obligations of care in the future, may limit mobility opportunities alongside gender and generation (Barglowski 2019a). These 
various accounts illustrate that social protection is embedded in different hierarchies, positioning migrants often ambivalently in the hierarchies of their countries of emigration and of immigration.

Formal and informal social protection are interrelated in many, and often unpredictable, ways which complicates a causal analysis of its interrelationship (e.g. Brandt \& Deindl, 2013). Conventionally, the informal was conceived of filling the gaps of formal protection (MacAuslan \& Sabates-Wheeler, 2011). For instance, when migrants cannot access welfare state benefits mainly due to not being able to transfer their formal rights and benefits (both from the countries of emigration and later from immigration), they tend to turn to their personal relationships that are supportive. Equally important is the lack of labour market inclusion of migrants that may mean a lower provision of formal protection. This situation might also encourage migrants to rely more on their interpersonal ties for protection. Through migration though, relevant people may not be available on short notice in daily lives and in case of emergencies. More generally, informal social protection is a distinct realm of division of responsibilities, exploitation and dominance depending on gender but also ethnicity, class, transnationality, and age.

In migration studies, previous research investigated both social support derived from migrants' personal networks as well as care relationship they exchange within families and kinship groups. While also being cautious about who gives what kind of support, research is well-established in depicting the personal relationships migrants have either locally (Ryan, 2011) or transnationally (Bilecen, 2016; Bilecen \& Cardona, 2018; Poeze, Dankyi, \& Mazzucato, 2017). After all, being confined only within ethnic networks comes not only with advantages such as emotional support and well-being but might also have disadvantages in terms of 'integration' (Anthias, 2007) and being able to reach only certain kinds of information that might result in employment or housing in certain 'lower' stratum (Portes \& Sensenbrenner, 1993). The focus on women in informal protection, particularly in the realm of care labour and relations, has for a long time neglected that migration has implications for men too. Very recent literature highlights migrant men's fathering (Parreñas, 2008; Roer-Strier, Strier, Este, Shimoni, \& Clark, 2005), masculinities (Ramirez, 2011; Vasquez del Aguila, 2014), and their increased involvement in care and household activities (Kilkey, Perrons, \& Plomien, 2013), pinpointing issues of how gendered identities, expectations, and norms which are also negotiated by men in the context of migration (see also Fiałkowska, 2019). Migration experiences also intersect with gendered experiences on labour markets and social status. As men's status is often derived from their position in labour markets, an intersectional perspective reveals ambivalences of men's status in transnational social spaces: in the immigration country they often suffer from ethnic discrimination, while their lack of labour market inclusion in the emigration country produces a lack of status, and lower formal protection (Barglowski, 2019a).

Studies of transnational families usually point at gendered dynamics of care arrangements across borders, for example, when mothers migrate in order to assure a better future for their children in the emigration countries (Baldassar \& Merla, 2014; Bryceson \& Vuorela, 2002; Lutz, 2017). It has been shown recently that gender intersects with class in the realm of care, for instance in relation to parenting young children in the immigration context (Barglowski, 2019b; Barglowski \& Pustułka, 2018). Care dominates much of the literature on migration and social protection, though research often faces 
hardships in placing "care work within a wider landscape of activities and sites and to connect supposedly disparate circuits of migration, in particular labour, family, and education, which are usually analysed separately but which are in fact interconnected" (Kofman, 2012, p. 144). The papers in this special issue therefore take into account not only care relations but also other forms of migrants' social protection, such as financial protection (Bilecen, 2019) and labour market inclusion (Castellani \& Martín-Díaz, 2019) in due consideration of their transnational networks, stages in their life course and the impacts on life chances arising from the exchange of protective resources (Faist, 2014).

\section{Gendered consequences of formal social protection arrangements for migrants}

Migrants do not only rely on informal protection, but also on formal protection (Sabates-Wheeler \& Feldman, 2011). The formal elements of a welfare state include a wide range of allowances and transfers (Geissler \& Pfau-Effinger, 2005; OECD 2007), such as family and child care allowances and pensions, unemployment benefits, subsidized and social housing, as well as institutional services, such as health services, early childhood education and care services and long-term care services including homes for the elderly which may be operated by a range of providers from the state to NGOs. Legal and immigration status, including purpose of permit (labour, family, humanitarian, study), and occupation are particularly relevant for access to formal provision and social entitlements. Particularly pertinent is the fact that women are over represented in informal sectors of work and as family migrants, often in the beginning without an independent legal status. Indeed, migrants usually negotiate both realms together, which calls for an integrated perspective which we aim to advance here. In the past 20 years many receiving states have drawn greater distinctions between different categories of migrants and their access to social rights and protection, thereby generating greater stratification between them (Kraler, 2010; Morris, 2002).

Similar to the informal social protection, due to international migration formal social protection regulations go through transformations as social policies are usually bound to nationstates, and access is often restricted by legal status, citizenship and/or labour market performance. These dimensions vary across countries and largely influence welfare state arrangements and exchange modes within social relations based mainly on normative ideals of gendered division of tasks. They constitute particular cultures of social policies and welfare states in relation to gender (Pfau-Effinger, 2005). Therefore, a more nuanced understanding of formal and informal protection in mobile contexts can be reached through a joint investigation of gender and transnationality, which play out in distinct welfare state arrangements.

In general, migration is seen as a challenge to the European welfare states' provisions (Bommes \& Geddes, 2002; Brücker et al., 2002) and portability situations (Sabates-Wheeler \& Feldman, 2011), as welfare states usually assume citizens to be subject to one welfare state over their life course. Although, the EU supports the rights of EU mobiles through a synchronization of national social policies, the regulations seem to be rather diverse. Thus, having only entitlements and legal access to certain welfare provisions does not necessarily mean that they can be actually accessed or received (MacAuslan \& Sabates-Wheeler, 2011). The accessibility of social protection also varies by mobility patterns, which are gendered. People who move as self-employed and for a short amount of time, which is often 
found in the male dominated construction sector, have a severely limited access to social protection. In some cases, people who move for a short time periods do not perceive themselves as beneficiaries of the welfare state arrangements in the countries of immigration (Fingarova, 2019). Similar patterns can be also found in the care sector, where usually women are hired on different legal conditions. At the same time, the fact that women often move as "family migrants" means that they, at least in the initial stage, do not have an independent legal status, besides their husbands' (Barglowski, 2019a). In light of the diversification and increasing rates of EU mobility, the intersections between transnationality, gender, migration patterns and social protection requires more systematic and joint analysis. With its legal norm of free movement within its borders and the on-going debates about supranational social policies, the EU provides an especially interesting case to further investigate transnational social protection both within and across the EU borders and the ambiguities between social rights and accessibility of social protection. While the EU facilitates the movement of its citizens and tends to enable them to access social entitlements and provisions, for non-EU migrants, access to formal social protection is often restricted by legal status and labour market performance, posing particular challenges to their life chances. The lack of coverage arising from their labour market participation therefore reduces the level of social protection available to large numbers of third-country migrants. Akin to informal protection, welfare regimes also reinforce gendered inequalities alongside social categories. Most prominently, it has been shown how welfare regimes rely on different concepts of gender and the roles men and women have in societies (Lutz, 2008; PfauEffinger, 2005). Papers in this special issue investigate multiple settings in terms of migrants' access, use, and negotiation of transnational social protection within the EU in the receiving as well as in the sending contexts (both EU and non-EU member countries) taking into account how formal and informal protection are entangled.

The access of third country nationals to formal social protection systems - composed of social security and social assistance services - of the EU is a recurrent topic because of its significance in extending and promoting social protection within and among European societies. From a rights-based perspective, although 'as a member of society' (Article 9 of the Universal Declaration on Human Rights and Fundamental Freedoms) every person is entitled to have a right to social security, citizenship plays a role, particularly in access to social assistance if not to social insurance. The EU is not an exception. EU rules have always favoured EU over non-EU citizens in access to formal social protection systems such as the above mentioned; what improved in the past was the position of non-EU citizens vis-à-vis EU-citizens, thus legitimizing the differences between them, i.e. unequal treatment between EU and non-EU migrants (Davy, 2014). While Article 18 of the EC Treaty guarantees EU citizens the right of free movement within the common market, albeit subject to other conditions ${ }^{1}$ within the Treaty, it draws a clear distinction between migrants with citizenship of EU member states and those who do

\footnotetext{
${ }^{1}$ Other conditions refer to the differences between migrants in terms of labor market inclusion. As the EC Treaty was originally directed not towards migrants, but to a mobile work force, those who are not integrated in the labour market and its social security schemes, must prove their self-sufficiency, i.e. students and retirees have to prove their own health care or retirement benefits (Becker, 2004). Therefore, there are also differences within EU migrants in terms of their access to formal protection (e.g. De Jong, De Valk, \& Van Mol, 2016; Zabransky \& Amelina, 2017). This is so because the harmonization of the EU labour market(s) is far more advanced than the social rights people have independently of their labor market status (Faist, 2014). It is a clear example of "negative integration" (market integration), in contrast to "positive integration" (social rights) (Scharpf, 1998).
} 
not. For example, the portability of benefits across borders is an important part in establishing a common EU labour market. The extent to which migrants can transport their accumulated benefits depends largely on their citizenship and country of residence indicating that not all third-country nationals are treated alike. For instance, migrants from association countries (e.g. Turkey, Morocco) have privileged access when it comes to rights regarding employment status. EU directives regulate the portability for third-country nationals based on the existence and structure of bilateral agreements. Directive 98/49/EC, for instance claims that vested pension rights of a person who leaves a pension scheme must be preserved to the same extent as if the person had not left it. That means that two comparable migrants in terms of age and education can be after migration subject to very different legal opportunities and constraints. Suppose we take two women in their thirties, engineers, one from Poland and one from Ukraine who have worked in the same profession before migrating to the UK. The opportunities for the Polish migrant woman in transferring the accumulated retirement benefits to the UK are very different than the Ukrainian one, placing the latter in a less privileged position because of her status as a third-country national.

For third country nationals there is a significant variation in the ways in which the different member states implement the recommendations and directives by the $\mathrm{EU}$ in terms of the conditions of access, the range and the financing of formal protection benefits. 'A majority of Member States require third-country nationals to hold long-term residence permits in order to access benefits that are financed through general taxation, especially family benefits, guaranteed minimum resources and long-term care benefits. However, there are important exceptions to this rule. For example, third-country nationals holding fixed-term residence permits qualify to receive non-contributory guaranteed minimum resources in fifteen Member States; non-contributory family benefits in ten Member States; and noncontributory old-age pensions in six Member States' (European Commission, 2014). For instance, all the insured population reaching retirement age (67 years), and fulfilling the general five-year period of employment, can claim retirement benefits regardless of their citizenship. When migrants would like to change their residency from Germany to another country for work or family reasons before they have paid contributions for 5 years, they can claim their pension contributions paid by themselves and not by the employers (which is to be transferred 2 years after their departure) (Müller, Mayer, \& Bauer, 2014). This policy affects mostly women who move due to family or care reasons before they have worked 5 years and lose the employer's contributions. Another example is Spain with a social security system with both contributory-based insurance and universal programmes. Under this welfare system, Spain provides benefits to all citizens and minimum benefits to residents regardless of their contributions or employment. While migrants need to be employed and have contributed to receive retirement and unemployment benefits, a few benefits can also be obtained through non-contributory schemes (Brey \& Stanek, 2013).

Although EU citizens enjoy freedom of movement within the EU, only those who have worked in the immigration country are entitled to welfare benefits (Ackers \& Coldron, 2009). The situation of the workforce from Eastern and South-Eastern European 
countries, such as Romania, Bulgaria and Poland, in Western and Northern (informal) labour markets is also particularly characterized by the low status of social protection and limited life chances. Their situation is also shaped by intra-EU inequality and the unequal terms of EU accession. Examples for intra-EU inequality were found in (albeit temporary) mobility restrictions imposed on the citizens of new member states, the fact that they often face de-qualification and precarious work conditions (Kahanec \& Zimmermann, 2010; Verwiebe, Wiesböck, \& Teitzer, 2014) and lower financial transfers to these countries (Bohle, 2006), which can be read as an indicator that inequality has not vanished through the legal and political incorporation of these countries into the EU. This is particularly true for those who are known to be subject to discrimination, such as 'Europe's largest minority' the Roma (Barr, 2005) and those who work in precarious employment, such as migrant women in domestic, agriculture, and tourism sectors, whose employment situation is characterized by a mix of informality and formality, and those migrants who are prone to a de-qualification and deskilling after migration. Lutz and PalengaMöllenbeck (2010) describe German policies in relation to the intersection of migration and care as a 'twilight zone' of 'compliance and complicity' toward the multiple contradictions regarding the declaration of the employment situation of migrant care workers, the vast majority being women. Inversely, the extent to which the work of a migrant care worker is undeclared or partially declared has a negative impact on the accumulation and general access to social protection benefits. The lack of standard contracts common in much domestic and care work in the household, as well as part-time employment have considerable impacts on gender inequalities in access to social entitlements during working life and in retirement, where the gender pension gap is significant in many EU countries (Burkevica, Humbert, Oetke, \& Paats, 2015; Möhring, 2015). Moreover, other gendered sectors such as construction, workers are sometimes forced to declare that they are self-employed (Barglowski, 2019a). In both cases, the end result pinpoints to the fact that no or totally insufficient formal social protection. This kind of exclusion affects both EU- and third-country-nationals alike.

The legal rights within the EU are a mixture of EU regulations and national regulations of the member states. Many EU countries have their own bilateral or multilateral agreements with some of the emigration countries of third country nationals. While the EU has issued directives to regulate the social security channels for its mobile populations including non-EU citizens, member-states have also concluded bilateral agreements with some of the migrants' countries of origin. An illustrative example is that requirements for permanent residency status range from 2 years of legal residency in Finland to 15 in Greece (Becker, 2004). For instance, Spain has bilateral agreements with countries of origin located in Africa, Eastern Europe (prior to their accession into the EU), and with a number of Latin American countries (Van Ginneken, 2013), while Germany has agreements with Australia, Bosnia Herzegovina, Brazil, Canada, Chile, China, Israel, Japan, Korea, Kosovo, Macedonia, Montenegro, Morocco, Serbia, Tunisia, Turkey, and the US in different sectors varying from healthcare, pensions to child allowances. However, as those agreements are highly fragmented in terms of their monetary scope and geographical coverage, thus posing challenges to harmonization of social security of third country nationals, the EU Commission is considering establishing an EU-wide social security agreement (European Commission, 2014). 
However, the challenge of protecting the rights that migrants might have acquired prior to their arrival to the countries of destination within the EU remains as an open question. Some advance has been made in agreements between Spain and Latin American, where there has been a slow, but steady, movement in bilateral and multilateral social security agreements, between Spain and 11 Latin American countries and the Ibero-American Multilateral Convention on Social Security which aims to preserve the rights of Spanish, Portuguese and Latin American workers, ensuring they retain their social rights and access to adequate social protection irrespective of their migrant status (Diaz Gorfinkiel \& Escriva, 2012).

\section{Overview of the articles}

Building on empirical studies, the papers in this special issue reveal the different ways social protection is organized and negotiated by migrants and their significant others across the countries of emigration and immigration. All the contributions analyse how social protection shapes and reshapes social inequalities in the context of migration with an emphasis on gender. In so doing, the papers contribute to the on-going debates on life chances of migrant populations in Europe. Specifically, papers aim to rethink the dynamics through which formal and informal social protection intersect with divisions of gender, ethnicity and class. Most importantly, are the logics of formal and informal protection similar when it comes to the divisions they (re)produce, or do they differ? In trying to find an answer to this complex question, the empirical studies assembled here are grounded in different methodologies and fields, however using the same analytical framework in terms of transnational social protection. Thus, the special issue offers a combination of theoretical, methodological and empirical perspectives on transnational social protection across many realms such as care, employment, and health.

The paper by Barglowski and Pustulka, (2018) focuses on the realm of childcare, which is particularly affected by inequalities for women, and shows how the different entanglements of formal and informal protections are shaped by gender and class. By drawing from a comparative study on Polish mothers in the UK and Germany, this study investigates early childcare choices of mothers as embedded in the different institutional contexts in Germany and in the UK. Within these different welfare regimes, migrant mothers strategize their childcare options according to their transnational social class.

Based on qualitative interviews and participant observation, the paper by Bilecen (2019) investigates one particular social protection strategy of Turkish migrant women in Germany that is organizing local networks based on gender, ethnicity, class, and marital status. Although informally organized, those networks have rather formal rules being transplanted and transformed from Turkey. Altın Günü (The Day of Gold) are the local networks of migrant women functioning as a type of rotating savings and credit association with implications on their immediate family members in Germany and extended ones in Turkey. The local networks of days of gold make financial and social capital available to their members for them to enjoy at rather gendered and hierarchized costs.

Fiałkowska's (2019) paper provides a rarely used perspective in research on gender and social protection, by including males' accounts on their involvement in family life 
and their understandings of their role as care givers. While men have usually been studied as providers of economic means, their absence also fundamentally changes the dynamics within the sending households. Based on fieldwork research both in Poland and in Germany conducted with seasonal male migrants Fiałkowska shows that fathers' absence might also cause troubles in family life, where family members get used to their absence. Furthermore, fathers are increasingly affected by changes in fathering roles, which makes them re-evaluate their position within families resulting in adaptation of their migration to the life stage of their children and to the requirements of family life.

The contribution of Camargo and Safuta (2019) combines research on domestic care workers' working conditions together with the legal regulations. The authors investigate both intra-EU and international migration to Belgium. The paper demonstrates realities and consequences of formal regulations, which often officially claim for a betterment of working conditions particularly for vulnerable groups, might not always be the case. The authors show that while the introduction of the voucher system in Belgium has provided domestic workers access to social protection, it did not change its devalued and underpaid character. As a result, domestic work still mainly attracts racialized and gendered minorities.

Based on extensive ethnographic research, Castellani and Martín-Díaz (2019) illuminate that social protection across borders is a source of tensions and conflicts within transnational families. The example of Ecuadorian women living in Spain demonstrates the complex processes through which gender roles transform at the intersection of social protection and employment, which oscillate between preservation of traditional gender relations and empowerment. Furthermore, from a capital-perspective, the authors shed light on the relevance of network-building and various forms of resources that can account as protective practices.

The paper by Sabates-Wheeler (2019) considers the formal social protection rights and needs of forcibly displaced populations with a gender lens. Within the context of the global social development goals, Sabates-Wheeler's contribution investigates different forms of social protection that may be needed by different groups who are forced to be displaced. The author argues for social protection policies going beyond standardized protection packages and targeting such populations whose needs are different than other types of mobile populations.

Acknowledgements

We are grateful to the funding received from German Research Foundation (DFG) within the framework of the Collaborative Research Centre 882 'From Heterogeneities to Inequalities'. We would also like to thank to the comments during which we have received at two workshops in IMISCOE conferences in 2013 and 2014.

Authors' contributions

$\mathrm{BB}, \mathrm{KB}, \mathrm{TF}$, and EK drafted the manuscript. All authors read and approved the final manuscript.

Funding

The guest editors of this special issue have organized two workshops in annual IMISCOE conferences in 2013 and 2014 where most of the papers are presented and discussed at length. Later, the editors had a meeting in Bielefeld in 2015 to further elaborate on the coherence of all the contributions and drafted the introductory paper. All those activities were funded by a grant from the German Research Foundation (DFG) within the framework of Collaborative Research Centre 882 'From Heterogeneities to Inequalities' at Bielefeld University. 


\section{Competing interests}

The authors declare that they have no competing interests.

\section{Author details}

'Department of Sociology, University of Groningen, Grote Rozenstraat 31, 9712 TG Groningen, the Netherlands. ${ }^{2}$ Center on Migration, Citizenship and Development, Bielefeld University, Bielefeld, Germany. ${ }^{3}$ Technical University Dortmund, Institute of Sociology, Emil-Figge-Str. 50, 44227 Dortmund, Germany. ${ }^{4}$ Bielefeld University, Faculty of Sociology, Universitätsstraße 25, 33615 Bielefeld, Germany. ${ }^{5}$ Middlesex University, School of Law, The Burroughs, London NW4 4BT, UK.

Received: 3 April 2019 Accepted: 9 October 2019

Published online: 11 December 2019

\section{References}

Ackers, L., \& Coldron, K. E. (2009). European citizenship, individual agency and the challenge to social welfare systems: A case study of retirement migration in the European Union. Policy and Politics, 37(4), 573-589.

Amelina, A. (2017). Transnationalizing inequalities in Europe: Sociocultural boundaries, assemblages and regimes of intersection. London: Routledge.

Anthias, F. (2009). Translocational belonging, identity and generation: Questions and problems in migration and ethnic studies. Finnish Journal of Ethnicity and Migration, 4(1), 5-15.

Anthias, F. (2016). Interconnecting boundaries of identity and belonging and hierarchy-making within transnational mobility studies: Framing inequalities. Current Sociology Monograph, 64(2), 172-190.

Anthias, F. (2007). Ethnic ties: social capital and the question of mobilisability. The Sociological Review 55(4): $788-805$.

Baldassar, L., \& Merla, L. (2014). Transnational families, migration and the circulation of care. Understanding mobility and absence in family life. London: Routledge.

Barglowski, K. (2019a). Cultures of transnationality in European migration. Subjectivity, family, inequality. New York/Abingdon: Routledge.

Barglowski, K. (2019b). Migrants' class and parenting: The role of cultural capital in migrants' inequalities in education. Journal of Ethnic and Migration Studies, 45(11), 1970-1987.

Barglowski, K., \& Pustułka, P. (2018). Tightening early childcare choices - Gender and social class inequalities among Polish mothers in Germany and the UK. Comparative Migration Studies, 6. https://doi.org/10.1186/s40878-018-0102-6.

Barr, N. (2005). (Ed) Labour Markets and Social Policy in Central and Eastern Europe. The Accession and Beyond. Washington, DC: The World Bank.

Becker, M. A. (2004). Managing diversity in the European Union: Inclusive European citizenship and third- country nationals. Yale Human Rights and Development Journal, 7(1), 5. Retrieved from http://digitalcommons.law.yale.edu/yhrdlj/vol7/iss1/5.

Bilecen, B. (2016). A personal network approach in mixed-methods design to investigate transnational social protection. International Review of Social Research, 6(4), 233-244.

Bilecen, B. (2019). 'Altın Günü': Migrant women's social protection networks. Comparative Migration Studies, 7. https://doi.org/ 10.1186/s40878-019-0114-X.

Bilecen, B., \& Barglowski, K. (2015). On the assemblages of informal and formal transnational social protection. Population, Space and Place, 21(3), 203-214.

Bilecen, B., \& Cardona, A. (2018). Do transnational brokers always win? A multilevel analysis of social support. Social Networks, $53,90-100$.

Boccagni, P. (2014). Caring about migrant care workers: From private obligations to transnational social welfare? Critical Social Policy, 34(2), 221-240.

Boccagni, P. (2017). Addressing transnational needs through migration? An inquiry into the reach and consequences of migrants' social protection across borders. Global Social Policy, 17(2), 168-187.

Bohle, D. (2006). Neoliberal hegemony, transnational capital and the terms of the EU's eastward expansion. Capital and Class, $30(1), 57-86$.

Bommes, M., \& Geddes, A. (Eds.) (2002). Immigration and welfare: Challenging the borders of the welfare state. London: Routledge.

Brandt, M., \& Deindl, C. (2013). Intergenerational transfers to adult children. Do social policies matter? Journal of Marriage and Family, 75(1), 235-251.

Brey, E. and Stanek, M. (2013) Mapping the conditions of stay and the rationale for entitlements and restrictions for family migrants in Spain. Retrieved from http://www.compas.ox.ac.uk/media/PR-2013-IMPACIM_Mapping_Spain.pdf .

Brücker, H., Epstein, G. S., McCormick, B., Saint-Paul, G., Venturini, A., \& Zimmermann, K. (2002). Managing migration in the European welfare state. In T. Boeri, G. Hanson, \& B. McCormick (Eds.), Immigration policy and the welfare system, a report for the Fondazione Rudolfo Debenedetti, (pp. 1-167). Oxford: Oxford University Press.

Bryceson, D. F., \& Vuorela, U. (Eds.) (2002). The transnational family. New European Frontiers and global networks. Oxford: Berg.

Burkevica, I., Humbert, A., Oetke, N., \& Paats, M. (2015). Gender gap in pensions in the EU. Research note to the Latvian Presidency. European Institute for Gender Equality. Vilnius: Lithuania.

Caarls, K., Haagsman, K., Kraus, E., \& Mazzucato, V. (2018). African transnational families: Cross-country and gendered comparisons. Population Space and Place, 24(7), e2162.

Cangiano, A., Shutes, I., Spencer, S. \& Leeson, G. (2009). Migrant Care Workers in Ageing Societies: Research Finding in the UK. Centre on Migration. Policy and Society. University of Oxford, Oxford.

Castellani, S., \& Martín-Díaz, E. (2019). Re-writing the domestic role: Transnational migrants' households between informal and formal social protection in Ecuador and in Spain. Comparative Migration Studies, 7. https://doi.org/10.1186/s40878-018-0108-0.

Daly, M., \& Lewis, M. (2000). The concept of social care and the analysis of contemporary welfare states. The British Journal of Sociology, 51(2), 281-292.

Davy, U. (2014). Sozialpolitik der Union [Social Policy of the Union]. In M. Niedobitek (Ed.), Die Politiken der Union, (pp. 771-911). Berlin/Boston: de Gruyter. 
De Jong, P., De Valk, H., \& Van Mol, C. (2016). Welfare, migration and the life course: Welfare regimes and migration patterns of EU-citizens in the Netherlands. (NIDI Working Paper No. 2016/02). The Hague: NIDI.

Diaz Gorfinkiel, M., \& Escriva, A. (2012). Care of older people in migration contexts: Local and transnational arrangements between Peru and Spain. Social Politics, 19(1), 129-141.

Dörr, S., \& Faist, T. (1997). Institutional conditions for the integration of immigrants in welfare states: A comparison of Germany, France, Great Britain, and the Netherlands. European Journal of Political Research, 31, 401-426.

European Commission (2014). Migrant access to social security and healthcare. European Migration Network Study. Retrieved from http://ec.europa.eu/dgs/home-affairs/what-we-do/networks/european_migration_network/reports/docs/emnstudies/final_synthesis_report_migrant_access_to_social_security_final_3july2014_en.pdf .

Faist, T. (2014). On the transnational social question: How social inequalities are reproduced in Europe. Journal of European Social Policy, 24(3), 207-222.

Faist, T. (2019). The transnationalized social question: Migration and the politics of social inequalities in the twenty-first century. Oxford: Oxford University Press.

Faist, T., \& Bilecen, B. (2015). Social inequalities through the lens of social protection: Notes on the transnational social question. Population, Space and Place, 21(3), 282-293.

Faist, T., Bilecen, B., Barglowski, B., \& Sienkiewicz, J. J. (2015). Transnational social protection: Migrants' strategies and patterns of inequalities. Population, Space, and Place, 21(3), 193-202.

Fiałkowska, K. (2019). Remote fatherhood and visiting husbands: Seasonal migration and men's position within families. Comparative Migration Studies, 7. https://doi.org/10.1186/s40878-018-0106-2.

Fingarova, J. (2019). Agency in transnational social protection: The practices of migrant families between Bulgaria and Germany (Doctoral dissertation). Technical University Cottbus-Senftenberg. Cottbus: Germany.

Geissler, B., \& Pfau-Effinger, B. (Eds.) (2005). Care and social integration in Europe. Bristol: Policy Press.

Glick Schiller, N., \& Wimmer, A. (2003). Methodological nationalism and beyond: Nation-state building, migration and the social sciences. Global Networks, 2(4), 301-334.

Haberkern, K., Schmid, T., \& Szydlik, M. (2013). Gender differences in intergenerational care in European welfare states. Ageing \& Society, 35, 298-320.

Jasso, G. (2011). Migration and stratification. Social Science Research, 40(5), 1292-1336.

Kahanec, M., \& Zimmermann, K. F. (Eds.) (2010). EU labor markets after post-enlargement migration. Berlin: Springer Berlin Heidelberg.

Kilkey, M., Perrons, D., \& Plomien, A. (2013). Gender, migration and domestic work. Masculinities, male labour and fathering in the UK and USA. Basingstoke: Palgrave.

Kilkey, M., Plomien, A., \& Perrons, D. (2014). Migrant men's fathering practices and projects in national and transnational spaces: recent Polish male migrants to London. International Migration 52(1), pp. 178-191.

Kofman, E. (2012). Rethinking care through social reproduction: Articulating circuits of migration. Social Politics, 19(1), $142-162$.

Kofman, E. (2014). Gendered migrations, social reproduction and the household in Europe. Dialectic Anthropology, 38(1), 79-94.

Kofman, E., \& Raghuram, P. (2015). Gendered migrations and global social reproduction. Basingstoke: Palgrave McMillan.

Kraler, A. (2010). Civic stratification, gender and family migration policies in Europe. Vienna: ICMPD.

Levitt, P., Viterna, J., Mueller, A., \& Llyod, C. (2017). Transnational social protection: Setting the agenda. Oxford Development Studies, 45(1), 2-19.

Locke, C., Seeley, J., \& Rao, N. (2013). Migration and social reproduction at critical junctures in family life course. Third World Quarterly, 34(10), 1881-1895.

Lutz, H. (Ed.) (2008). Migration and domestic work. A European perspective on a global theme. Aldershot: Ashgate

Lutz, H. (2017). Euro orphans - the stigmatization of migrant motherhood. In Y. Ergas, J. Jenson, \& S. Michel (Eds.), Reassembling motherhood. Procreation and care in a globalized world, (pp. 247-268). New York: Columbia University Press.

Lutz, H., \& Palenga-Möllenbeck, E. (2010). Care work migration in Germany: Semi-compliance and complicity. Social Policy and Society, 9(3), 419-430.

MacAuslan, I., \& Sabates-Wheeler, R. (2011). Structures of access to social provision for migrants. In R. Sabates-Wheeler, \& R. Feldman (Eds.), Migration and social protection. Claiming rights beyond borders, (pp. 61-87). New York: Palgrave Macmillan.

Möhring, K. (2015). Employment histories and pension incomes in Europe. European Societies, 17(1), 3-26.

Morris, L. (2002). Managing Migration: Civic stratification and Migrants' Rights. London: Routledge.

Müller, A., Mayer, M. M., \& Bauer, N. (2014). Social security for third-country nationals in Germany, working paper 57. Nueremberg: Federal Office for Migration and Refugees. Retrieved from http:/www.bamf.de/SharedDocs/Anlagen/ EN/Publikationen/EMN/Nationale-Studien-WorkingPaper/emn-wp57-soziale-absicherung\%20drittstaatsangehoeriger. pdf? blob=publicationFile.

Organization for Economic Cooperation and Development (OECD) (2007). The Social Expenditure database: An Interpretive Guide. Paris: OECD. Retrieved from https://stats.oecd.org/OECDStatDownloadFiles/OECDSOCX2 007InterpretativeGuide_En.pdf.

Orloff, A. (1996). Gender in the welfare state. Annual Review of Sociology, 22(1), 51-78.

Parreñas, R. S. (2001). Mothering from a distance. Emotions, gender, and inter-generational relations in Filipino transnational families. Feminist Studies, 27(2), 361-391.

Parreñas, R.S. (2008). The Force of Domesticity: Filipina Migrants and Globalization. New York: New York University Press.

Parreñas, R.S. (2005). Children of Global Migration: Transnational Families and Gendered Woes. Stanford, CA: Stanford University Press.

Pfau-Effinger, B. (2005). Welfare state policies and the development of care arrangements. European Societies, 7(2), 321-347.

Poeze, M., Dankyi, E., \& Mazzucato, V. (2017). Navigating transnational childcare relationships: Migrant parents and their children's caregivers in the origin country. Global Networks, 17(1), 111-129.

Portes, A., \& Sensenbrenner, J. (1993). Embeddness and immigration: Notes on the social determinants of economic action. American Journal of Sociology, 98(6), 1320-1350.

Ramirez, H. (2011). Masculinity in the workplace: The case of Mexican immigrant gardeners. Men and Masculinities, 14(1), 97-116.

Roer-Strier, D., Strier, R., Este, D., Shimoni, R., \& Clark, D. (2005). Fatherhood and immigration: Challenging the deficit theory. Child and Family Social Work, 10(4), 315-329. 
Ryan, L. (2011). Migrants' social networks and weak ties: Accessing resources and constructing relationships post-migration. The Sociological Review, 59(4), 707-724.

Sabates-Wheeler, R. (2019). Mapping differential vulnerabilities and rights: 'Opening' access to social protection for forcibly displaced populations. Comparative Migration Studies, 7. https://doi.org/10.1186/s40878-019-0142-6.

Sabates-Wheeler, R., \& Feldman, R. (Eds.) (2011). Migration and social protection. Claiming rights beyond borders. New York: Palgrave Macmillan.

Safuta, A., \& Camargo, B. (2019). The more things change, the more they stay the same? The impact of formalising policies on personalisation in paid domestic work - the case of the service voucher in Belgium. Comparative Migration Studies, 7. https://doi.org/10.1186/s40878-018-0111-5.

Sainsbury, D. (2006). Immigrants' social rights in comparative perspective: Welfare regimes, forms in immigration and immigration policy regimes. Journal of European Social Policy, 16(3), 229-244.

Scharpf, F. W. (1998). Negative and positive integration in the political economy of European welfare states. In M. Rhodes, \& Y. Mény (Eds.), The future of European welfare: A new social contract? (pp. 157-177). Basingstoke: Palgrave.

Seibel, V., \& Hedegaard, T. F. (2017). Migrants' and natives' attitudes to formal childcare in the Netherlands, Denmark and Germany. Children and Youth Services Review, 78, 112-121.

Serra Mingot, E., \& Mazzucato, V. (2018). Providing social protection to mobile populations: Symbiotic relationships between migrants and welfare institutions. Journal of Ethnic and Migration Studies, 44(13), 2127-2143.

Van Ginneken, W. (2013). Social protection for migrant workers: National and international policy challenges. European Journal of Social Security, 15(2), 209-221.

Vasquez del Aguila, M. (2014). Being a man in a transnational world. The masculinity and sexuality of migration. London: Routledge.

Verwiebe, R., Wiesböck, L., \& Teitzer, R. (2014). New forms of intra-European migration, labour market dynamics and social inequality in Europe. Migration Letters, 11(2), 125-136.

Vullnetari, J., \& King, R. (2008). 'Does your granny eat grass?' On mass migration, care drain and the fate of older people in rural Albania. Global. Networks 8(2), pp. 139-171.

Weiss, A. (2005). The Transnationalization of social inequality: Conceptualizing social positions on a world scale. Current Sociology, 53(4), 707-728.

Zabransky, F. \& Amelina, A. (2017). Intra-EU mobility and selective European social citizenship: Profiles of welfare inclusion and exclusion in the context of EU social security coordination (WSF Working Papers TRANSWEL \#2, September 2017).

\section{Publisher's Note}

Springer Nature remains neutral with regard to jurisdictional claims in published maps and institutional affiliations.

\section{Submit your manuscript to a SpringerOpen ${ }^{\circ}$ journal and benefit from:}

- Convenient online submission

Rigorous peer review

- Open access: articles freely available online

- High visibility within the field

- Retaining the copyright to your article

Submit your next manuscript at $\boldsymbol{\nabla}$ springeropen.com 